\title{
Earthworms - The Environmental Engineers: Review of Vermiculture Technologies for Environmental Management \& Resource Development
}

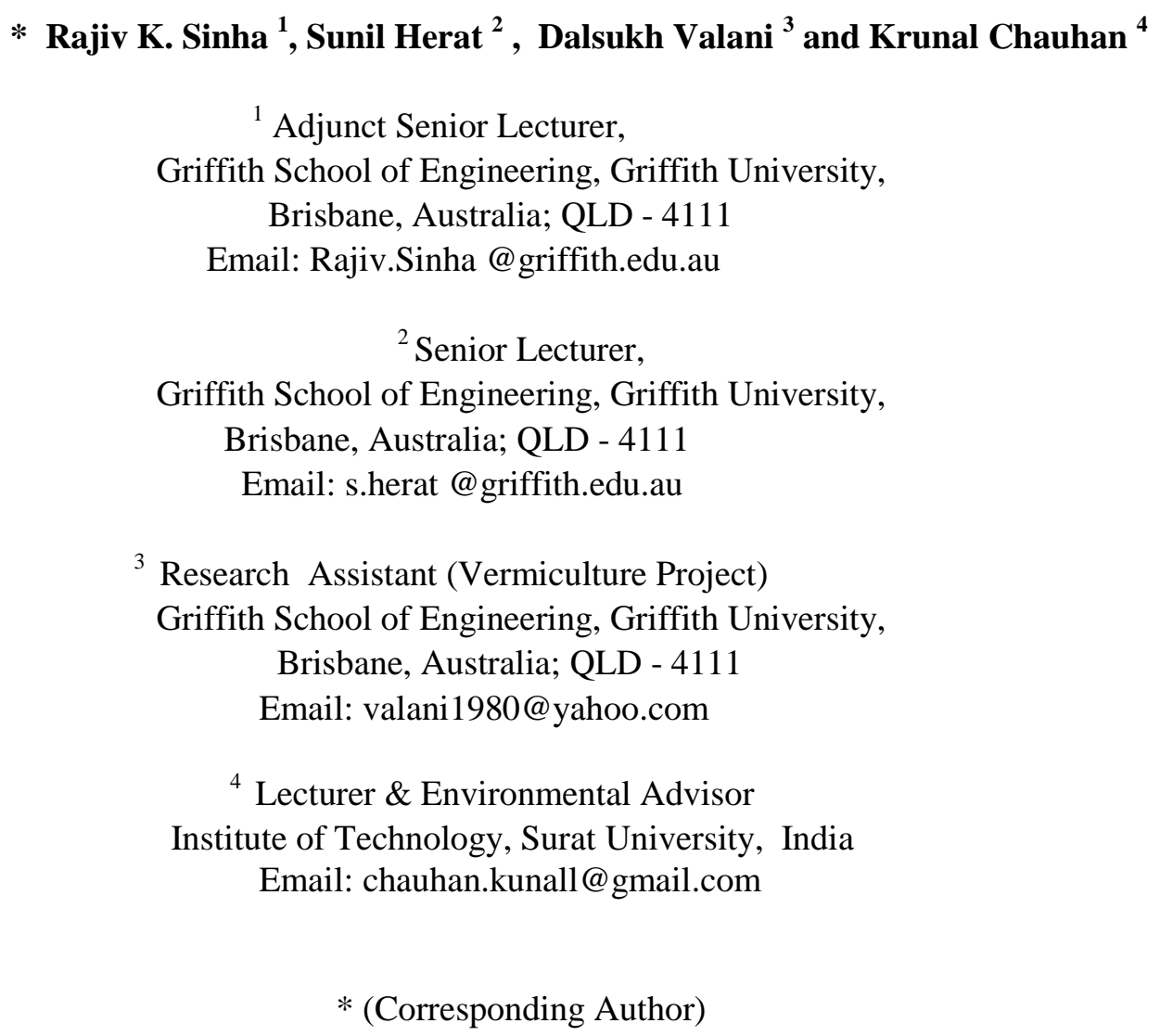

Abstract: Vermiculture is sustainable' technology to manage most organic wastes; treat wastewater; clean-up chemically contaminated soils; improve soil fertility and produce food crops. Use of earthworms in production of life-saving medicines and raw materials for industries are some 'new discoveries'. We have successfully experimented in vermicomposting of 'MSW', vermifiltration of 'municipal \& industrial wastewater', vermiremediation of chemically contaminated soils' and production of 'cereal \& vegetables crops' with excellent results. Wastes are degraded by over $75 \%$ faster, BOD and TDSS of wastewater is reduced by over $95 \%$ and growths of crop plants are enhanced by 30-40\% higher over chemical fertilizers, by worms \& vermicast.

Keywords: Vermicomposting of Wastes; Vermifiltration of Wastewater; Vermiremediation of Contaminated Lands; Vermi-agroproduction of Organic Foods; Vermicompost - Nutritive Biofertilizer; Earthworms Biomass - A Valuable Resource for Pharmaceutical Industries.

Reference to this paper should be made as follows: Sinha, R.K., Herat, S., and Valani, D. (2010) 'Earthworms - The Environmental Engineers: Review of Vermiculture Technologies for Environmental Management \& Resource Development ', Int. J. of Environmental Engineering, In Rajiv K Sinha, Sunil Herat \& Sunita Agarwal (Eds.) Special Issue on 
'Vermiculture Technology for Environmental Management and Resource Development, Vol. X, No. Y., pp. 000000.

Biographical notes: Dr. Rajiv K. Sinha is Senior Lecturer at Griffith University. He is in academics since 1971 in India and since 2000 in Australia. He has published over 130 papers in International Journals and 20 books on environmental issues and produced $7 \mathrm{Ph}$.Ds. He has gained International recognition in Vermiculture Research. His focus of research is on 'Vermifiltration' of municipal \& industrial wastewater and 'Vermiremediation' of contaminated soils (Innovative Technologies); 'Vermicomposting' of solid wastes and developing the vermicompost as sustainable alternative to the chemical fertilizers. He is the principal ‘Guest Editor’ of the present Special Issue on Vermiculture Technology.

Dr Sunil Herat is Senior Lecturer at Griffith University. His research interests include solid waste management, cleaner production and electrical and electronic wastes. He was instrumental in establishing the sole E-Waste research centre in Australia. He has published over 50 research papers in international peer-reviewed journals. He has also presented in number of international conferences and appeared in number of media interviews. Dr Herat is a current member of United Nation's Solving the E-waste Problem (StEP) taskforce on capacity building. He is also one of the 'Guest Editors' of the present Special Issue on Vermiculture Technology.

Dalsukh Valani did is Bachelor in 'Agriculture Engineering' from India (2003) and Masters in 'Environmental Engineering’ with Honours from Griffith University, Australia in 2007-09. He did his 'Vermiculture Project’ under Rajiv K. Sinha \& Dr. Sunil Herat. He has also published some 10 papers in vermiculture studies.

Krunal Chauhan did his Bachelor in 'Chemical Engineering' from India (2003) and Masters in ‘Environmental Engineering’ with Honours from Griffith University, Australia in 2007-09. He did his ‘Vermiculture Project' under Rajiv K. Sinha \& Dr. Sunil Herat. He is currently Lecturer and Environmental Advisor at Surat University, India. He has also published some 8 papers in vermiculture studies.

\section{1). Introduction}

The global scientific community today is searching for a technology which should be 'economically viable’, ‘environmentally sustainable’ and 'socially acceptable'. Vermiculture Technologies based on the use of earthworms combines all these virtues together. Earthworms have over 600 million years of experience as 'environmental engineers'. 
Vermiculture scientists all over the world knew about their role as 'waste \& soil engineers' and 'plant growth promoters' for long time. But some 'new discoveries' about their role in 'wastewater treatment', and 'contaminated soil remediation' and presence of some valuable 'bioactive compounds' for production of 'modern medicines' and raw materials for some consumer industries have revolutionized the studies into vermiculture.

\section{2). Technologies for Environmental Management by Use of Earthworms}

Following technologies for environmental protection can be envisaged by the use of useful earthworms species which promises to provide cheaper solutions to several social, economic, environmental \& health problems plaguing the human society -

1). 'THE VERMICOMPOSTING TECHNOLOGY' (Worms as WASTE ENGINEERS) for efficient management of municipal \& industrial solid wastes (organics) by biodegradation \& stabilization and converting them into useful resource (vermicompost - a nutritive biofertilizer);

2). 'THE VERMIFILTRATION TECHNOLOGY' (Worms as WASTEWATER ENGINEERS) for treatment of municipal and some industrial wastewater, their purification \& disinfection for reuse;

\section{3). 'THE VERMIREMEDIATION TECHNOLOGY' (Worms as BIOCHEMICAL} ENGINEERS) for cleaning up chemically contaminated lands while also improving the total physical, chemical and biological properties of soil for reuse;

4). 'THE VERMI-AGROPRODUCTION TECHNOLOGY'(Worms as SOIL ENGINEERS) for restoring \& improving soil fertility to produce safe and chemical-free food for the society by the use of vermicompost $\&$ without recourse to the destructive agro-chemicals;

Bioengineering technologies based on earthworms are self-promoted, self-regulated, selfimproved \& self-enhanced, low or no-energy requiring zero-waste technologies, easy to construct, operate and maintain. They excel all 'bio-conversion', 'bio-degradation' \& 'bioproduction' technologies by the fact that they can utilize organics that otherwise cannot be utilized by others. They excel all 'bio-treatment' technologies because they achieve greater utilization than the rate of destruction achieved by other technologies. They involve about 100-1000 times higher 'value addition' than other biological technologies. (Appeholf, 1997; Wang, 2000).

\section{3). Vermicomposting Technology}

We are facing the escalating socio-economic and environmental cost of dealing with current and future generation of mounting municipal solid wastes (MSW). Another serious cause of concern today is the emission of greenhouse gases (GHG) methane $\left(\mathrm{CH}_{4}\right)$ \& nitrous oxides 
$\left(\mathrm{N}_{2} \mathrm{O}\right)$ resulting from the disposal of MSW either in the waste landfills or from their management by composting. Millions of tons of MSW generated from the modern society are ending up in the landfills everyday, creating extraordinary economic and environmental problems for the local government to manage and monitor them (may be up to 30 years) for environmental safety (emission of GHG, toxic gases and leachate discharge into ground water). Construction of secured engineered landfills incurs 20-25 million U.S. dollars before the first load of waste is dumped. Over the past 5 years the cost of landfill disposal of waste has increased from \$ 29 to \$ 65 per ton of waste in Australia. During 2002 - 2003, waste management services within Australia cost \$ 2458.2 millions. In 2008-2009 it was over \$5000 millions.

Waste degradation \& composting by earthworms is proving to be economically \& environmentally preferred technology over the conventional composting technologies as it is rapid and nearly odorless process, reducing composting time by more than half and the end product is both 'disinfected', 'detoxified' and 'highly nutritive'. Visvanathan et al., (2005) found that most earthworms consume, at the best, half their body weight of organics in the waste in a day. Eisenia fetida can consume organic matter at the rate equal to their body weight every day. Earthworm participation enhances natural biodegradation and decomposition of organic waste from 60 to $80 \%$. And as the worms double their population every 60-70 days, the process becomes faster with time. Given the optimum conditions of temperature $\left(20-30{ }^{\circ} \mathrm{C}\right.$ ) and moisture (60-70\%), about $5 \mathrm{~kg}$ of worms (numbering approx.10,000) can vermiprocess 1 ton of waste into vermi-compost in just 30 days.

\subsection{Wastes Handled by Earthworms}

Waste eater earthworms can physically handle a wide variety of organic wastes from both municipal (domestic and commercial) and industrial streams (Loehr et,al.,1984;Datar, 1997; Fraser-Quick, 2002; \& Sinha et, al., 2005). 


\section{Municipal Solid Wastes}

The food waste from homes (both raw \& cooked) and restaurants. The garden wastes (leaves and grass clippings) also constitute an excellent feedstock for vermi-composting. The 'sewage sludge' from the municipal water \& wastewater treatment plants and the paunch waste materials (gut contents of slaughtered ruminants) from abattoir also make good feedstock for earthworms (Edwards, 1988 \& 1998; Fraser-Quick, 2002; Sinha et al., 2009 c).

Agriculture and Animal Husbandry Wastes

Farm wastes e.g. crop residues, dry leaves \& grasses. Livestock rearing waste e.g. cattle dung, pig and chicken excreta makes excellent feedstock for earthworms.

\section{Some Industrial Organic Wastes}

Solid waste from paper pulp and cardboard industry, food processing industries including brewery and distillery; vegetable oil factory, sugarcane industry, aromatic oil extraction industry, sericulture industry, logging and carpentry industry also make excellent feedstock for vermicomposting (Edwards, 1988 \& 1998; Kale, 1998). Worms can also compost 'flyash' from coal power plants (Saxena et. al., 1998). Worms have also been found to degrade and vermicompost complex organic materials like 'asphaltens' from the oil drilling sites (Martin-Gel et al., 2007).

\subsection{Earthworms Species Suitable for Waste Degradation \& Composting}

Long-term researches into vermiculture have indicated that the Tiger Worm (Eisenia fetida), Red Tiger Worm (E. andrei), the Indian Blue Worm (Perionyx excavatus), the African Night Crawler (Eudrilus euginae), and the Red Worm (Lumbricus rubellus) are best suited for vermi-composting of variety of organic wastes (Graff, 1981; Beetz, 1999; Sinha et. al, 2002).

\subsection{Our Studies on Vermicomposting of MSW}

Sinha et. al., (2009 d) studied the vermicomposting of mixed food \& garden wastes and compared with conventional aerobic composting without worms. 1000 worms (Eisinea fetida) were used. Mixed food waste consisted of both cooked and raw e.g. boiled rice, noodles, pasta \& potatoes; baked bread \& buns; cooked \& raw green vegetables; fruits \& vegetables peels \& cuts. Garden wastes consisted of mostly grass clippings. Food wastes degraded $100 \%$ in just 
15 days while garden wastes in 60 days. Degradation of food wastes had started within hours ( $5 \%$ after 24 hours). Cooked food wastes were more easily degraded. In wastes where the primary cellulosic materials were intact e.g. leaves and grasses, raw vegetables $\&$ fruits or where there are brittle calcium compounds e.g. egg shells, were degraded rather more slowly by the earthworms. In the conventional composting system without worms, maximum degradation of both food \& garden wastes were only $35 \%$ even after 90 days of the study period. (Table - 1).

\section{Insert Table 1 Here.}

Sinha et al, (2009 a) also studied about the 'food preferences' of waste eater earthworms when provided with different food wastes of both plant $\&$ meat products. They showed clear likings for baked bread \& buns followed by raw tomato, boiled potato, lettuce, pumpkin \& baked beans and then for boiled rice \& noodles and banana peels. They do not like 'raw potato \& onion'. A most significant finding was that when left to starve without any vegetable food products, they are forced to feed upon even on 'meat products' as the last food preference. Food wastes containing meat products were however, badly infected by fungus and 'maggots' for few days emitting foul odour, but eventually controlled by the worms.

\subsection{Mechanism of Worm Action in Vermicomposting}

Earthworms promotes the growth of 'beneficial decomposer aerobic bacteria' in waste biomass and also act as an aerator, grinder, crusher, chemical degrader and a biological stimulator. (Dash, 1978; Binet et al., 1998). Earthworms hosts millions of decomposer (biodegrader) microbes in their gut (Singleton et al., 2003). Edward and Fletcher (1988) showed that the number of bacteria and 'actinomycetes' contained in the ingested material increased up to 1000 fold while passing through the gut. A population of worms numbering about 15,000 will in turn foster a microbial population in billions in short time. Under favorable conditions, earthworms and microorganisms act 'symbiotically \& synergistically' to accelerate and enhance the decomposition of the organic matter in the waste. It is the microorganisms which breaks down the cellulose in the food waste, grass clippings and the leaves from garden wastes. (Morgan \& Burrows, 1982).

The waste feed materials ingested is finely ground (with the aid of stones in their muscular gizzard) into small particles to a size of 2-4 microns and passed on to the intestine for enzymatic actions. The gizzard and the intestine work as a 'bioreactor'; The worms secrete enzymes proteases, lipases, amylases, cellulases and chitinases in their gizzard and intestine which bring about rapid biochemical conversion of the cellulosic and the proteinaceous materials in the waste organics. (Dash, 1978). 
The final process in vermi-processing and degradation of organic matter is the 'humification' in which the large organic particles are converted into a complex amorphous colloid containing 'phenolic' materials. Only about one-fourth of the organic matter is converted into humus.

\subsection{Advantages of Vermicomposting Technology}

Earthworms have real potential to both increase the rate of aerobic decomposition and composting of organic matter by over $75 \%$ and also to stabilize the organic residues in the MSW and sludge - removing the harmful pathogens and heavy metals from the compost. The quality of compost is significantly improved, rich in key minerals \& beneficial soil microbes (Edwards, 2000). In fact in the conventional aerobic composting process which is thermophilic (temperature rising up to $55{ }^{\circ} \mathrm{C}$ ) many beneficial microbes are killed and nutrient especially nitrogen is lost (due to gassing off of nitrogen). Earthworms create aerobic conditions in the waste materials by their burrowing actions, inhibiting the action of anaerobic micro-organisms which release foul-smelling hydrogen sulfide and mercaptans. The earthworms release coelomic fluids that have anti-bacterial properties and destroy all pathogens in the resulting compost. (Pierre et al.,1982). The greatest advantage over the conventional composting system is that the end product is more homogenous, richer in 'plantavailable nutrients \& humus' and significantly low contaminants. They are 'soft', 'highly porous' with greater 'water holding capacity' (Hartenstein \& Hartenstein, 1981; Appelhof, 1997;Lotzof, 2000).

Studies have established that vermicomposting of wastes by earthworms significantly reduce the total emissions of greenhouse gases in terms of $\mathrm{CO}_{2}$ equivalent, especially nitrous oxide $\left(\mathrm{N}_{2} \mathrm{O}\right)$ which is 296-310 times more powerful GHG than $\mathrm{CO}_{2}$. Our studies showed that on average, vermicomposting systems emitted $463 \mathrm{CO}_{2}$-e $/ \mathrm{m}^{2} /$ hour respectively. This is significantly much less than the landfills emission which is $3640 \mathrm{CO}_{2}$-e $/ \mathrm{m}^{2} /$ hour. Vermicomposting emitted minimum of $\mathrm{N}_{2} \mathrm{O}-1.17 \mathrm{mg} / \mathrm{m}^{2} /$ hour, as compared to Aerobic Composting (1.48 mg / $\mathrm{m}^{2} /$ hour) and Anaerobic Composting (1.59 mg / $\mathrm{m}^{2} /$ hour). Hence, earthworms can play a good part in the strategy of greenhouse gas reduction and mitigation in the disposal of global MSW.(Sinha and Chan, 2009).

\subsection{Commercial Vermicomposting : A Global Movement \& Booming Business}

Vermicomposting of diverse organic wastes and use of vermicompost in agriculture is being commercialized all over the world from developed countries like U.S., Canada, U.K., Australia, Russia and Japan to developing countries like India, China, Chile, Brazil, Mexico, Argentina and the Philippines (Bogdanov, 1996; Sherman, 2000). 
U.S. has some largest vermicomposting plants in world and States are encouraging people for 'backyard vermicomposting' to divert wastes from landfills. (Bogdanov, 1996 \& 2004). The 'American Earthworm Company' started a 'vermicomposting farm' in 1978-79 with $500 \mathrm{t}$ /month of vermicompost production (Edward, 2000). 'Vermicycle Organics' produced 7.5 million pounds of vermicompost every year in high-tech greenhouses. Its sale of vermicompost grew by $500 \%$ in 2005. 'Vermitechnology Unlimited' has doubled its business every year since 1991. (NCSU, 1997; Kangmin, 1998).

A large scale vermicomposting plant has been installed in Canada to vermicompost municipal and farm wastes (GEORG, 2004). In UK, large 1000 metric ton vermicomposting plants have been erected in Wales to compost diverse organic wastes (Frederickson, 2000). In France, 20 tons of mixed household wastes are being vermicomposted everyday using 1000 to 2000 million red tiger worms (Elsenia andrei) in earthworm tanks. (Visvanathan et al., 2005).

The 'Envirofert Company' of New Zealand is vermicomposting about 5-6 thousand tons of green waste every year. They are also planning to vermicompost approximately 40,000 tones of food wastes from homes, restaurants and food processing industries every year. (www.envirofert.co.nz) (Frederickson, et. al., 2000).

Vermicomposting is being done on large scale in Australia as a part of the 'Urban Agriculture Development Program' utilizing the urban solid wastes (Lotzof, 2000). Vermicomposting of sludge from the sewage and water treatment plants is being increasingly practiced in Australia and as a result it is saving over $13,000 \mathrm{~m}^{3}$ of landfill space every year in Australia (Komarowski, 2001; Dynes, 2003).

India has also launched vermicomposting program of MSW. In recent years it is growing as a part of 'village \& farm waste management', 'sustainable non-chemical agriculture' combined with 'poverty eradication' program. It has enhanced the lives of poor in India and generated self-employment opportunities for the unemployed. In several Indian villages NGO's are freely distributing cement tanks and 1000 worms and encouraging men \& women to collect waste from villages \& farmers, vermicompost them and sell both worms and vermicompost to the farmers (Suhane, 2007; NIIR, 2009).

\section{4). Vermifiltration Technology}

We are also facing the escalating socio-economic and environmental cost of dealing with current and future generation of mounting municipal and industrial wastewater. Over $80 \%$ of the potable water used by society return as wastewater. Conventional treatment results into formation of 'sludge' which requires safe disposal in 'secured landfills' at additional cost.

Vermifiltration of wastewater using waste eater earthworms is a newly conceived novel technology with several advantages over the conventional systems. Earthworms body work as 
a 'biofilter' and they have been found to remove the 5 days biological oxygen demand $\left(\mathrm{BOD}_{5}\right)$ by over $90 \%$, chemical oxygen demand (COD) by 80-90\%, total dissolved solids (TDS) by 90-92 \% and the total suspended solids (TSS) by 90-95 \% from wastewater by the general mechanism of 'ingestion' and biodegradation of organic wastes and also by their 'absorption' through body walls. Suspended solids are trapped on top of the vermifilter and processed by earthworms and fed to the soil microbes immobilized in the vermifilter. Worms also remove chemicals including heavy metals and pathogens from treated wastewater (Bajsa, et, al. 2003) and the treated water becomes fit \& also nutritive for 'reuse' in irrigation of parks.

\subsection{Earthworms Species Suitable for Vermifiltration of Wastewater}

The same waste eater species of worms e.g. Eisenia fetida, Perionyx excavatus, Eudrilus euginae and Lumbricus rubellus that are suitable for composting solid wastes are also suited for vermi-filtration of wastewater. Eisinea fetida has been found to be more versatile.

\subsection{Critical Factors Affecting Vermifiltration of Wastewater}

a). Worm Biomass:

As the earthworms play the critical role in wastewater purification their number and population density (biomass) in soil, maturity and health are important factors. This may range from several thousands to millions. There are reports about 8-10,000 numbers of worms per square meter of the worm bed and in biomass as $10 \mathrm{~kg}$ per $\mathrm{m}^{3}$ of soil for optimal function (Komarowski, 2001).

\section{b). Hydraulic Retention Time:}

It is also very essential for the wastewater to remain in contact with the worms in the filter bed for certain period of time. This is called 'hydraulic retention time'. HRT depends on the flow rate of wastewater to the vermifiltration unit, volume of soil profile and quality of soil used. The longer wastewater remains in the system in contact with earthworms, the greater will be the efficiency of vermi-processing and retention of nutrients. The number of live adult worms, functioning per unit area in the vermifilter (VF) bed can also influence HRT. High hydraulic loading rate leads to reduced hydraulic retention time (HRT) in soil and could reduce the treatment efficiency. 


\subsection{Some Important Studies on Vermifiltration}

Soto and Toha (1998) studied the vermifiltration of municipal wastewater in a pilot plant for treating wastewater of 1000 inhabitants and found that the BOD load was removed by $99 \%$, TSS by 95\%, VSS (volatile suspended solids) by $96 \%$, nitrogen (N) by $89 \%$ and phosphorus (P) by $70 \%$. The vermifilter bed was prepared of stones at the bottom and sawdust above with 20-30 cm humus at the top in which 5000 -10,000 earthworms (Eisenia andrea) per square meter were released. E. coli (M.P.N.) was removed by 1000 fold. Such systems allowed to treat $1000 \mathrm{~L} / \mathrm{m}^{2}$ / of wastewater per day. They have commercialized and patented the technology in Chile.

A pilot study on vermifiltration of sewage was made by Xing et al,. (2005) at Shanghai Quyang Wastewater Treatment Facility in China. The earthworm bed which was $1 \mathrm{~m}$ (long) $\mathrm{x}$ $1 \mathrm{~m}$ (wide) x 1.6m (high), was composed of granular materials and earthworms. The worm's number was kept at about 8000 worms/sqm. The average chemical oxygen demand (COD) value of raw sewage used was $408.8 \mathrm{mg} / \mathrm{L}$ that of 5 days biological oxygen demand $\left(\mathrm{BOD}_{5}\right)$ was $297 \mathrm{mg} / \mathrm{L}$ that of suspended solids (SS) was $186.5 \mathrm{mg} / \mathrm{L}$. The hydraulic retention time varied from 6 to 9 hours and the hydraulic loading from 2.0 to $3.0 \mathrm{~m}^{3} /\left(\mathrm{m}^{2} . \mathrm{d}\right)$ of sewage. The removal efficiency of COD ranged between $81-86 \%$, the $\mathrm{BOD}_{5}$ between $91-98 \%$, and the SS between $97-98 \%$.

\subsection{Our Studies on Vermifiltration of Municipal \& Industrial Wastewater}

Sinha et, al., (2008 a) studied the vermifiltration of sewage obtained from the Oxley Wastewater Treatment Plant in Brisbane, Australia. They also studied the vermifiltration of brewery \& dairy wastewaters. The experiment was carried out in a 220 L capacity 'vermicomposting bin' with provisions for dripping wastewater from the top and collecting the filtered water at bottom through an outlet. Vermifilter bed was prepared by organizing pebbles at bottom of the bin and about $30 \mathrm{~cm}$ layer of soil on top in which worms were released. A control bin was also organized which had pebbles and soil bed but no earthworms. The pebbles and soil (with microbes) can also be expected to contribute in the filtration of wastewater.

Results showed that the earthworms removed BOD $\left(\mathrm{BOD}_{5}\right)$ loads of sewage by over $99 \%$ at hydraulic retention time (HRT) of 1-2 hours. Average COD removed from the sewage by earthworms is over $50 \%$. COD removal was not very significant, but at least much higher than the control. Earthworms also removed the total suspended solids (TSS) from the sewage by over $90 \%$ (Table -2$)$. 


\section{Insert Table 2 here}

Sinha et, al., (2007) also studied the vermifiltration of brewery and milk dairy wastewaters which have very high $\mathrm{BOD}_{5}$ and TSS loadings e.g. $6780 \mathrm{mg} / \mathrm{L} \& 682 \mathrm{mg} / \mathrm{L}$ respectively from brewery and 1,39,200 $\mathrm{mg} / \mathrm{L} \& 3,60,00 \mathrm{mg} / \mathrm{L}$ respectively from the dairy industry. Earthworms removed the high $\mathrm{BOD}_{5}$ loads by $99 \%$ in both cases and TSS by over $98 \%$. But the hydraulic retention times (HRTs) in case of brewery wastewater was 3-4 hours and 6-10 hours for the dairy wastewater.

An important observation was that although the BOD, COD and the TSS of wastewater were also considerably removed by the control system (devoid of earthworms) it never worked for longer time and frequently got choked. The organic solids in the wastewater accumulated as peat in the soil layer and also attracted heavy 'fungal infection'. It became un-operational after sometimes. In the vermifiltration system the earthworms constantly fed upon the solids and the fungus and never allowed the system to be choked and become un-operational.

\subsection{The Mechanism of Worm Action in Vermifiltration}

The twin processes of microbial stimulation \& biodegradation, and the enzymatic degradation of waste solids by worms simultaneously work in the vermifiltration system. Vermifilters provide a high specific area - up to $800 \mathrm{sq} \mathrm{m} / \mathrm{g}$ and voidage up to $60 \%$. Suspended solids are trapped on top of the vermifilter and processed by earthworms and fed to the soil microbes immobilized in the vermifilter.

Intensification of soil processes and aeration by the earthworms enable the soil stabilization and filtration system to become effective and smaller in size. Earthworms intensify the organic loadings of wastewater in the vermifilter soil bed by the fact that it granulates the clay particles thus increasing the 'hydraulic conductivity' of the system. They also grind the silt and sand particles, thus giving high total specific surface area, which enhances the ability to 'adsorb' the organics and inorganic from the wastewater passing through it. The vermicast produced on the soil bed also offers excellent hydraulic conductivity of sand (being porous like sand) and also high adsorption power of clay. (Bhawalkar, 1995).

\subsection{Advantages of Vermi-filtration Technology Over Conventional Wastewater Treatment} Technologies

Vermi-filtration of wastewater is low energy \& efficient system and has distinct advantage over all the conventional wastewater treatment systems - the 'Activated Sludge Process', 'Trickling Filters' and 'Rotating Biological Contactors' which are highly energy intensive, 
costly to install and operate and do not generate any income. In the vermifilter process there is $100 \%$ capture of organic materials, the capital and operating costs are less, and the end products (vermicompost \& vermifiltered disinfected \& detoxified nutritive water) and byproducts (earthworms biomass) are of great economic uses.

\section{a). No Sludge Formation:}

Since the conventional technologies are mostly the flow-processes and have finite hydraulic retention time (HRT) it always results into a 'residual stream' of complex organics and heavy metals (while only the simple organics are consumed by decomposer microbes) in the form of 'sludge'. This plagues most municipal councils in world as the sludge is a 'biohazard' and requires safe landfill disposal at high cost. The greatest advantage of vermifiltration system is that there is no formation of 'sewage sludge' (Huges et. al., 2005). The worms decompose the organics in the wastewater and also devour the solids (which forms the sludge) synchronously. They feed readily upon the sludge components, rapidly convert them into vermicompost, reduce the pathogens to safe levels and ingest the heavy metals.

\section{b). No Foul Odor:}

There is no foul odor as the earthworms arrest rotting and decay of all putrescible matters in the wastewater and the sludge.

In all developed nations a 'worm farm' has become a necessity in all wastewater \& water treatment plants to resolve the sludge problems.

\section{c). Disinfected \& Detoxified Water Fit for Non-Potable Uses:}

Vermifiltered water is free of pathogens and toxic chemicals (heavy metals \& endocrine disrupting chemicals) and suitable for 'reuse' as water for non-potable purposes. The worms devour on all the pathogens (bacteria, fungus, protozoa \& nematodes) in the medium in which they inhabit. They have the capacity to bio-accumulate high concentrations of toxic chemicals in their tissues and the resulting wastewater becomes almost chemical-free.

\section{d). Worms Remove Endocrine Disrupting Chemicals from Sewage:}

Earthworms have also been reported to bio-accumulate 'endocrine disrupting chemicals' (EDCs) from sewage which otherwise is not removed by our conventional sewage treatment plants (STPs). Markman et al. (2007) have reported significantly high concentrations of EDCs 
(dibutylphthalate, dioctylphthalate, bisphenol-A and $17 \beta$ - estrdiol) in tissues of earthworms (E. fetida) living in sewage percolating filter beds and also in garden soil.

\section{e). Nutritive Water Fit for Park Irrigation:}

The vermifiltered water also becomes 'highly nutritive' rich in NKP and other nutrients as the worms release them into water during the process. The water is very suitable for irrigation in parks and golf courses.

\subsection{Vermifiltration Technology: Destined to Become Commercial \& Global}

If a vermifilter bed of $0.3 \mathrm{~m}^{3}$ soil is prepared with approximately 5000 worms (over $2.5 \mathrm{~kg}$ ) to start with, it can easily treat 950 - $1000 \mathrm{~L}$ of domestic wastewater / sewage generated by (on an average) a family of 4 people with average BOD value ranging between $300-400$

mg/L, COD 100 - $300 \mathrm{mg} / \mathrm{L}$, TSS, 300 - $350 \mathrm{mg} / \mathrm{L}$ everyday with hydraulic retention time (HRT) of the wastewater in the vermifilter bed being approximately 1 - 2 hours. Given that the worms multiply and double its number in at least every 60 days under ideal conditions of temperature and moisture, even starting with this number of earthworms a huge population (biomass) of worms with robust vermi-filtration system can be established quickly within few months which will be able to treat greater amount of wastewater generated in the family. An important consideration is the peak hour wastewater generation which is usually very high and may not comply with the required HRT (1 - 2 hrs) which is very critical for sewage treatment by vermi-filtration system. To allow $1-2$ hrs HRT in the vermifilter bed an onsite domestic wastewater storage facility will be required from where the discharge of wastewater to the vermifilter tank can be slowly regulated through flow control.

Due to its simplicity and cost-effectiveness vermifiltration of both municipal and industrial wastewater is destined to become a global movement. In Chile, over 100 sewage treatment plants of different sizes, going from individual houses to plants for 12,000 persons and bigger plants for industries are already working. It has been introduced on commercial scale in Mexico and Venezuela (Soto \& Toha, 1998). India and Brazil are also introducing the technology on commercial scale. Some companies in Pune (India) have already started pilot plants.

\section{5). Vermiremediation Technology}

Large tract of arable land is being chemically contaminated due to mining activities, heavy use of agro-chemicals in farmlands, landfill disposal of toxic wastes and other developmental activities like oil and gas drilling. No farmland of world especially in the developing nations are free of toxic pesticides, mainly aldrin, chlordane, dieldrin, endrin, heptachlor, mirex and 
toxaphene. Traditionally, remediation of chemically contaminated soils involves 'off-site' management by excavating and subsequent disposal by burial in secured landfills. This method of remediation is very costly affair and merely shifts the contamination problem elsewhere. Additionally, this involves great risk of environmental hazard while the contaminated soils are being transported and 'migration of contaminants' from landfills into adjacent lands and water bodies by leaching. Soil washing for removing inorganic contaminants from soil is another alternative to landfill burial, but this technique produce a 'residue' with very high metal contents which requires further treatment or burial. Since the late 1980s, after the chemical and mechanical treatments of lands and water bodies and thermal treatment (incineration) of hazardous wastes proved economically and environmentally unsustainable, focus shifted towards the biological methods which are costeffective as well as environmentally sustainable and also socially acceptable.

Vermiremediation (using chemical tolerant earthworm species) is emerging as a low-cost and convenient technology for cleaning up the chemically polluted /contaminated sites / lands in world. Earthworms in general (specially E. fetida) arehighly resistant to many chemical contaminants including heavy metals and organicpollutants in soil. They have been reported to bio-accumulate them in their tissues andeither biodegrade or bio-transform them to harmless products with the aid of enzymes.They have also been reported to host microbes in their gut which can biodegrade chemicals. Ramteke and Hans (1992) isolated hexachlorocyclohexane $(\mathrm{HCH})$ degrading microorganisms from the gut of earthworms.

Earthworms have been used for land recovery, reclamation and rehabilitation of sub-optimal soils such as poor mineral soils, polder soils, open cast mining sites, closed landfill sites and cutover peat (Lowe \& Butt, 2003 and Butt et al., 2004). Within the soil environment, an earthworm's sphere of influence is known as the 'drilosphere system'. This incorporates the burrow systems, surface and belowground earthworm casts, internal earthworm gut and process, the earthworm surface in contact with the soil, and associated biological, chemical and physical interactions, in addition to the soil microorganisms (Brown and Doube, 2004).

Earthworms in general are highly resistant to many chemical contaminants including heavy metals and organic pollutants in soil and have been reported to bio-accumulate them in their tissues. After the Seveso chemical plant explosion in 1976 in Italy, when vast inhabited area was contaminated with certain chemicals including the extremely toxic TCDD (2,3,7,8tetrachlorodibenzo-p-dioxin) several fauna perished but for the earthworms that were alone able to survive. Earthworms which ingested TCDD contaminated soils were shown to bioaccumulate dioxin in their tissues and concentrate it on average 14.5 fold. (Satchell, 1983). 
Experiments have established that it is possible to generate an earthworm population of 0.2 1.0 million per hectare of land within a short period of three months for vermiremediation task. Given the optimal conditions of moisture, temperature and feeding materials earthworms can multiply rapidly to produce a huge army of worms in a short time (Bhawalkar, 1995) .

\subsection{Earthworm Species Suitable for Land Remediation (Soil Decontamination)}

Certain species of earthworms such as Eisenia fetida, Aporrectodea tuberculata, Lumbricus terrestris, L. rubellus, Dendrobaena rubida, D. veneta, Eiseniella tetraedra, Allobophora chlorotica have been found to tolerate and remove wide range of chemicals from soil. Our study also indicate that E. fetida is most versatile chemical bio-accumulators. Earthworms have been found to bioaccumulate heavy metals, pesticides and lipophilic organic micropollutants like the polycyclic aromatic hydrocarbons (PAH) from the soil.

E. fetida was used as the test organisms for different soil contaminants and several reports indicated that E. fetida tolerated $1.5 \%$ crude oil (containing several toxic organic pollutants) and survived in this environment. (Safwat et al., 2002).

\subsection{Some Important Studies on Vermiremediation Technology}

Hartenstein et al., (1980), studied that earthworms can bio-accumulate high concentrations of heavy metals like cadmium $(\mathrm{Cd})$, mercury $(\mathrm{Hg})$, lead $(\mathrm{Pb})$ copper $(\mathrm{Cu})$, manganese $(\mathrm{Mn})$, calcium (Ca), iron (Fe) and zinc ( $\mathrm{Zn})$ in their tissues. They can particularly ingest and accumulate extremely high amounts of zinc ( $\mathrm{Zn})$, lead $(\mathrm{Pb})$ and cadmium (Cd). Cadmium levels up to $100 \mathrm{mg}$ per kg dry weight have been found in tissues. Ireland (1983) reported that the earthworms species Lumbricus terrestris can bio-accumulate in their tissues $90-180 \mathrm{mg}$ lead $(\mathrm{Pb})$ / gm of dry weight, while L. rubellus and D. rubida it was $2600 \mathrm{mg} / \mathrm{gm}$ and 7600 $\mathrm{mg} / \mathrm{gm}$ of dry weight respectively.

Ma et. al,. (1995) studied the influence of earthworms species L. rubellus on the disappearance of spiked PAHs phananthrene \& fluoranthene (100 $\mu \mathrm{g} / \mathrm{kg}$ of soil) and found that the losses of both PAHs occurred at a faster rate in soils with earthworms, than the soil without worms. After 56 days (8 weeks), $86 \%$ of the phenanthrene was removed. ContrerasRamos et.al, (2006) studied the uptake of three PAHs viz. phenanthrene, anthracene and benzo(a)pyrene at different concentrations by E. fetida and measured the PAHs concentrations in the soil and in the tissues of earthworms exposed to the PAHs for 11 weeks. The concentration of anthracene decreased by 2-fold after addition of earthworms and the average removal was $51 \%$ which was only $23 \%$ by microbes alone when the earthworms were not added to the soil. On an average the concentration of benzo(a)pyrene decreased by 
1.4- fold and the average removal was $47 \%$ which was only $13 \%$ by microbes when earthworms were not present. Phenanthrene was completely removed (100 \%) by earthworms when the amount of the chemical was $<100 \mathrm{mg} / \mathrm{kg}$ of soil, while only $77 \%$ was removed by microbes in absence of earthworms.

Schaefer (2005) studied that increased microbial catabolic activity due to the presence of Eisinia fetida was responsible for the loss of $91 \%$ (1074 mg / kg of soil to $96 \mathrm{mg} / \mathrm{kg}$ ) of crude oil contamination in 56 days of treatment.

Studies indicated that the earthworms bio-accumulate or biodegrade 'organochlorine pesticide' and 'polycyclic aromatic hydrocarbons' (PAHs) residues in the medium in which it lives. (Davis, 1971; Ireland, 1983; Haimi et, al., 1992; Eijackers et al., 2001 \& Gevao et al., 2001). Bolan \& Baskaran (1996) studied the effect of earthworm species Lumbricus rubellus \& Allobophora callignosa vermicast on the sorption and movement of herbicides $\mathrm{C}^{14}$ metsulforon methyl, $C^{14}$ - atrazine, $C^{14}-2,4$ dichlorophenoxyacetic acid $(2,4-D)$ in soil. Worm vermicasts sorbed higher amount of herbicides from the contaminated soil than the control soil.

Singer et, al., (2001) studied the role of earthworm species Pherertime hawayana in mixing and distribution of PCB-degrader microorganisms when added to 'Aroclor 1242' contaminated soil (100 mg / kg of soil) over 18 weeks period. The contaminated soil treated with earthworms resulted in significantly greater PCB losses (average $52 \%$ ) when compared to the soil without earthworm treatment which was $41 \%$.

\subsection{Our Studies on Vermiremediation of PAHs Contaminated Soil}

Sinha et, al., (2008 b) studied the remedial action of earthworms on PAHs contaminated soils obtained from a former gas works site in Brisbane where gas was being produced from coal. The initial concentration of total PAHs compounds in the soil at site was greater than 11,820 $\mathrm{mg} / \mathrm{kg}$ of soil. The legislative requirements for PAHs concentration in soil in Australia is only $100 \mathrm{mg} / \mathrm{kg}$ for industrial sites and $20 \mathrm{mg} / \mathrm{kg}$ for residential sites. PAHs contaminated soil was subjected to three treatments and studied for 12 weeks. 60-70\% moisture was maintained in soil. (Table - 3).

\section{Insert Table 3 here}

Results showed that the worms could remove nearly $80 \%$ of the PAHs (or above $60 \%$ after taking the dilution factors into consideration) as compared to just $47 \%$ \& $21 \%$ where it was not applied and only microbial degradation occurred. This was just in 12 weeks study period. It could have removed by $100 \%$ in another few weeks. More significant was that the worm 
added soil became odor-free of chemicals in few days and were more soft and porous in texture.

\subsection{Mechanism of Worm Action in Vermiremediation}

Earthworms uptake chemicals from the soil through passive 'absorption' of the dissolved fraction through the moist 'body wall' in the interstitial water and also by mouth and 'intestinal uptake' while the soil passes through the gut. Earthworms apparently possess a number of mechanisms for uptake, immobilization and excretion of heavy metals and other chemicals. They either 'bio-transform' or 'biodegrade' the chemical contaminants rendering them harmless in their bodies. Some metals are bound by a protein called 'metallothioneins' found in earthworms which has very high capacity to bind metals. The chloragogen cells in earthworms appears to mainly accumulate heavy metals absorbed by the gut and their immobilization in the small spheroidal chloragosomes and debris vesicles that the cells contain (Ireland, 1983). Ma et al., (1995) found that earthworms biodegrade organic contaminants like phthalate, phenanthrene and fluoranthene.

\subsection{Advantages of Vermiremediation Technology Over the Mechanical \& Chemical} Treatment Technologies of Contaminated Lands

The greatest advantage of the vermiremediation technology is that it is 'on-site' treatment and there is no additional problems of 'earth-cutting', 'excavation' and 'transportation' of contaminated soils to the landfills or to the treatment sites incurring additional economic and environmental cost. Vermiremediation would cost about \$ 500 - 1000 per hectare of land as compared to $\$ 10,000$ - 15,000 per hectare by mechanical excavation of contaminated soil \& its landfill disposal.

Significantly, vermiremediation leads to total improvement in the quality of soil and land where the worms inhabit. They swallow large amount of soil everyday, grind them in their gizzard and digest them in their intestine with aid of enzymes. Only 5-10 percent of the digested and ingested material is absorbed into the body and the rest is excreted out in soil in the form of fine mucus coated granular aggregates called 'vermicastings' which are rich in NKP (nitrates, phosphates and potash), micronutrients and beneficial soil microbes including the 'nitrogen fixers' and 'mycorrhizal fungus'.

And what is of still greater economic and environmental significance is that the polluted land is not only 'cleaned-up' but also 'improved in physical, chemical \& biological quality'. A 'wasteland' is transformed into 'wonderland'.

\subsection{Vermi-remediation Technology Destined to Become a Global Movement}


Vermiremediation by commercial vermiculture in U.K. 'Land Reclamation and Improvements Programs' has become an established technology for long-term soil decontamination, improvement \& maintenance, without earth-cutting, soil excavation and use of chemicals'. U.S., Australia and other developed nations are also following (Butt, 1999).

\section{6). Vermi-agroproduction Technology}

Vermi-agroproduction technology promises to usher in the 'Second Green Revolution' by completely replacing the destructive agro-chemicals which did more harm than good to both the farmers and their farmland during the 'First Green Revolution' of the 1950-60's. Earthworms restore \& improve soil fertility and boost crop productivity by the use of their metabolic product - 'vermicast'. They excrete beneficial soil microbes, and secrete polysaccharides, proteins and other nitrogenous compounds into the soil. They promote soil fragmentation and aeration, and bring about 'soil turning' and dispersion in farmlands. Importance of earthworms in growth of pomegranate fruit plants was indicated by the ancient Indian scientist Surpala in the $10^{\text {th }}$ Century A.D. in his epic 'Vrikshayurveda' (Science of Tree Growing) (Sadhale, 1996).

\subsection{Vermicompost : A Highly Nutritive Bio-fertilizer Superior to Chemical Fertilizers}

Vermicompost is a nutritive plant food rich in NKP, macro \& micronutrients, beneficial soil microbes like 'nitrogen-fixing bacteria' and 'mycorrhizal fungi' and are excellent growth promoters (Buckerfield, et al.,1999). Kale \& Bano (1986) reports as high as $7.37 \%$ of nitrogen $(\mathrm{N})$ and $19.58 \%$ phosphorus as $\mathrm{P}_{2} \mathrm{O}_{5}$ in worms vermicast). Neilson (1965) \& Tomati et. al., (1987) reported presence of 'plant growth hormones' (auxins, gibberlins \& cytokinins) in vermicompost. Vermicompost also contain enzymes like amylase, lipase, cellulase and chitinase (Chaoui et al., 2003). More significantly, vermicompost contains 'humus' which makes it markedly different from other organic fertilizers. It takes very long time for soil or any organic matter to decompose to form humus while earthworms secrete humus in its excreta. Without humus plants cannot grow and survive. The humic acids in humus are essential to plants in four basic ways - 1). Enables plant to extract nutrients from soil; 2). Help dissolve unresolved minerals to make organic matter ready for plants to use; 3). Stimulates root growth; and, 4). Helps plants overcome stress (Kangmin, 1998).

Atiyeh et al. (2000) found that the vermicompost tended to be higher in 'nitrates', which is the more bio-available form of nitrogen for plants. Suhane (2007) found that the total bacterial count was more than $10^{10} /$ gm of vermicompost. It included Actinomycetes, Azotobacter, 
Rhizobium, Nitrobacter \& Phosphate Solubilizing Bacteria ranges from $10^{2}-10^{6}$ per gm of vermicompost.

\subsection{Some Important Studies on Vermi-agroproduction Technology}

Edwards \& Burrows (1988) found that vermicompost consistently improved seed germination, enhanced seedling growth and development, and increased plant productivity. The growth responses of plants from vermicompost appears more like 'hormone-induced activity' associated with the high levels of nutrients, humic acids and humates in vermicompost. Baker \& Barrett (1994) at CSIRO Australia found that the earthworms can increase growth of wheat crops by $39 \%$, grain yield by $35 \%$, lift protein value of the grain by $12 \%$ \& fight crop diseases. Palainsamy (1996) also studied that earthworms \& its vermicast improve the growth and yield of wheat by more than $40 \%$.

Arancon et, al., (2004) studied the agronomic impacts of vermicompost and chemical fertilizers on strawberries. Vermicompost was applied @ 10 tons / ha while the inorganic fertilizers (nitrogen, phosphorus, potassium) @ 85 (N)- 155 (P) - 125 (K) kg / ha. The 'yield' of marketable strawberries and the 'weight' of the 'largest fruit' was greater on plants in plots grown on vermicompost as compared to inorganic fertilizers in 220 days after transplanting. Also there were more 'runners' and 'flowers' on plants grown on vermicompost. Webster (2005) studied the agronomic impact of vermicompost on cherries and found that it increased yield of 'cherries' for three (3) years after 'single application'. Buckerfield \& Webster (1998) found that worm-worked waste (vermicompost) boosted grape yield by two-fold as compared to chemical fertilizers.

\subsection{Our Studies on Growth Impacts of Worms \& Vermicompost on Crop Plants}

a). Sinha et al,. (2009 b) studied the growth impacts of earthworms and their vermicompost on potted egg and okra plants. Results are given in tables $4 \& 5$.

\section{Insert Table 4 here \\ Insert Table 5 here}

b). Sinha et al,. (2009) studied the growth impacts of earthworms and their vermicompost on potted corn plants and compared with chemical fertilizers $(\mathrm{NPK}+\mathrm{Mg}+\mathrm{S}+\mathrm{Fe}+\mathrm{B}+\mathrm{Zn}$ ). Results are given in table -6 .

\section{Insert table 6 here}

Vermicompost with earthworms in soil achieved excellent growth over chemical fertilizers. While the plants on chemicals grew only $5 \mathrm{~cm}(87 \mathrm{~cm}$ to $92 \mathrm{~cm}$ ) in 7 weeks (week 7 - 19), 
those on vermicompost with worms grew by $15 \mathrm{~cm}(90 \mathrm{~cm}$ to $105 \mathrm{~cm})$ within the same period. Corn plants with worms \& vermicompost also attained maturity very fast.

c). Sinha et al,. (2009 b) studied the growth impacts of earthworms with vermicompost on potted wheat plants and compared with chemical fertilizers $(\mathrm{NPK}+\mathrm{Mg}+\mathrm{S}+\mathrm{Fe}+\mathrm{B}+\mathrm{Zn})$ \& conventional compost (cow manure). Results are given in table- 7.

\section{Insert table 7 here}

Wheat crops on vermicompost with worms maintained very good growth from the very beginning \& achieved maturity very fast. Plants were greener and healthier over others, with large numbers of tillers \& long seed ears at maturity. Seeds were healthy and nearly 35-40 \% more as compared to plants on chemical fertilizers.

d). Sinha et al,. (2009 b) also studied the growth impacts of vermicompost on wheat crops in farms in India. Vermicompost supported yield better than chemical fertilizers and had other agronomic benefits. It significantly reduced the demand for irrigation by nearly 30-40 \%. Soil tests indicated better availability of essential micronutrients and useful microbes. There was significantly 'less incidence of pests and disease attacks' in vermicompost applied crops which reduced use of chemical pesticides by over $75 \%$. (Table -8 ).

\section{Insert Table 8 here}

\subsection{Advantages of Vermiculture Agriculture Over Chemical Agriculture}

The biggest advantage of great social significance is that the food produced is completely organic 'safe \& chemical-free'. Studies indicate that vermicompost is at least 4 times more nutritive than the conventional composts and gives 30-40\% higher yield of crops over chemical fertilizers. In Argentina, farmers consider it to be seven (7) times richer than conventional composts in nutrients and growth promoting values (Pajon - Undated). Vermicompost retains nutrients for long time. Of greater agronomic significance is that the minerals in the vermicompost are 'readily \& immediately bio-available' to the plants. Chemical fertilizers (and also manures) have to be broken down in the soil before the plants can absorb. The humus in vermicompost also helps chemical fertilizers become more effective (Kangmin, 1998).

Vermicompost also has very 'high porosity', 'aeration', 'drainage' and 'water holding capacity' than the conventional compost. This is mainly due to the 'humus content' present in the vermicompost. Thus vermicompost use reduces the requirement of water for irrigation by $30-40 \%$. Another big advantage of great economic \& environmental significance is that production of vermicompost (locally from community wastes) is at least $75 \%$ cheaper than 
the chemical fertilizers (produced in factories from vanishing petroleum products generating waste \& pollution). And over successive years of application, vermicompost 'build-up the soils natural fertility' improving its total physical, chemical and biological properties. On the contrary, with the continued application of chemical fertilizers over the years the 'natural fertility of soil is destroyed' and it becomes 'addict'. Subsequently greater amount of chemicals are required to maintain the same yield \& productivity of previous years.

Another advantage of great environmental significance is that vermicompost 'suppress plant disease' in crops and inhibit the soil-born fungal diseases. In field trials with pepper, tomatoes, strawberries and grapes significant suppression of plant-parasitic nematodes has been found. There is also significant decrease in arthropods (aphids, buds, mealy bug, spider mite) populations with $20 \%$ and $40 \%$ vermicompost additions. (Edwards \& Arancon, 2004). Humus in vermicast extracts 'toxins', 'harmful fungi \& bacteria' from soil \& protects plants. Actinomycetes in vermicast induces 'biological resistance' in plants against pests \& diseases. As such use of vermicompost significantly reduces the need for 'chemical pesticides'.

\subsection{Global Movement for Ecological Agriculture by Vermiculture to Replace the Destructive} Chemical Agriculture

Worldwide farmers are desperate to get rid of the vicious circle of the use of chemical fertilizers as their cost have been constantly rising and also the amount of chemicals used per hectare has been steadily increasing over the years to maintain the yield \& productivity of previous years. Nearly 3 - 4 times of agro-chemicals are now being used per hectare what was used in the 1960s. In Australia, the cost of MAP fertilizer has risen from AU \$ 530.00 to AU \$ 1500.00 per ton since 2006. So is the story everywhere in world. Farmers urgently need a sustainable alternative which is both economical and also productive while also maintaining soil health \& fertility.

A movement is going on among Australian \& Canadian farmers to vermicompost all their farms wastes and supplement them with reduced doses of chemical fertilizers. Municipal councils and composting companies are also participating in vermicomposting business, composting all types of organic wastes on commercial scale and selling them to the farmers. This has dual benefits. Cutting cost on landfill disposal of waste while earning revenues from sale of worms \& vermicompost (Lotzof, 2000; Munroe, 2007 \& Sinha et. al., 2009 b).

In India a movement is going on to motivate farmers to embrace vermiculture. A number of villages in state of Bihar have been designated as 'Bio-Village' where the farmers have completely switched over to organic farming by vermicompost and have given up the use of chemical fertilizers for the last four years since 2005. 


\section{Vermiculture for Resource Development}

In any vermiculture practice 'vermicompost' (degraded products of waste organics used as feed stock for worms) and 'earthworms biomass' comes as a valuable by-product. Vermicompost is like a 'brown gold' to produce 'green gold' (food crops) as we have discussed above. Worm biomass is also proving to be a great 'biological resource' for mankind.

\subsection{Bioactive Compounds from Earthworms for Pharmaceutical Industries}

Current researches made in Canada, China, Japan and other countries on the identification, isolation and synthesis of some 'bioactive compounds' from earthworms (Lumbricus rubellus \& Eisenia fetida) with potential medicinal values have brought revolution in the vermiculture studies (Wang, 2000; Wengling and Jhenjun, 2000). In the last 10 years, a number of earthworm's 'clot-dissolving', 'lytic' and 'immune boosting' compounds have been isolated and tested clinically. Some of these compounds have been found to be enzymes exhibiting ‘anti-blood clotting' effects (Cordero, 2005). Oral administration of earthworms powder \& enzymes were found to be effective in treating 'thrombotic diseases', 'arthritis', 'diabetes mellitus', 'pulmonary heart disease’, 'lowering blood pressure’, ‘epilepsy', 'schizophrenia', 'mumps', 'exzema', 'chronic lumbago', 'anemia', 'vertigo' and 'digestive ulcer' (Mihara et. al., 1990). Scientist have also isolated 'bronchial dilating' substance from earthworms.

Researchers at Quinghua University, China has extracted 4 valuable medicinal compounds from earthworms - a large molecular compound which has 'anti-carcinogenic' effects; medium molecular compound which has 'anti - thrombosis' \& 'thrombus dissolution' effects; a small molecular compounds which contain 17 kinds of amino acids, polymers, trace elements and vitamins; and a $4^{\text {th }}$ product which can cure burns and scalds (Kangmin, 1998). Mihara et al., 1992 also extracted enzymes lumbritin, lumbrofebrin, terrestrolumbrolysin and 'lumbrokinase' enzymes from Lumbricus rubellus useful in thrombolytic therapy.

\section{a). Medicines for Heart Diseases}

Lumbrokinase (LK) is a group of 6 'proteolytic enzymes' and recent researches suggest that it may be effective in treatment and prevention of 'ischemic heart disease' as well as 'myocardial infarction', 'thrombosis’ of central vein of retina, 'embolism' of peripheral veins, and 'pulmonary embolism' (Qingsui, 2003). It is now being used in the treatment of 'cerebral infarction' (Jin et. al,. 2000). The enzymes also shows some potential in prosthetic care of patients who have received prosthetic vascular grafts (Hwang et, al., 2002). Japanese scientists also confirmed the curative effects of 'lumbrokinase' experimentally in the 1980s. 
Fibrinolysin and fibrinokinase are other important enzymes extracted from earthworms which has high 'cellulolytic activity' as well as 'proteolytic activity'. They can reduce the viscosity of blood and apparently has beneficial effects on 'paralysis of limbs' or 'aphasia' caused by cerebro-vascular disease (Wang et, al., 2003). Collagenase was another valuable enzyme extracted from earthworms which can cure 'thrombus' type diseases. It can cleave peptide bonds in timeworn, triple-helical collagen. Because of its unique ability to hydrolyze timeworn collagen it can be used to cut the strong outer cover of an old thrombus (blood clot). This enables the other two enzymes - fibrinolysin and fibrinokinase to enter into the thrombus and dissolve it thus opening the blood vessel and restoring oxygen supply (Kangmin, 1998). Some fatty acids found in earthworms are of great value in modern medicine. The oleic acid which is an Omega - 9 monounsaturated fatty acids has great medicinal value in lowering the risks of 'heart attack' and 'arteriosclerosis' and in the prevention of cancer. Linoleic acid found in earthworms is also of great medicinal value. In human body it is converted into 'gamma linoleic acid' (GLA) and ultimately to 'prostaglandins', hormone like molecules that help regulate inflammation and 'blood pressure' as well as 'heart', 'gastro-intestinal' and 'kidney’ functions (Li, 1995 \& Lopez \& Alis, 2005).

\section{b). Cancer Cure by Earthworms ?}

Cooper (2009) found that earthworms 'leukocytes' can recognize human cancer cells as 'foreign' and can kill them. A peptide 'lumbricin' isolated from Lumbricus terrestris by a Japanese scientist has been shown to 'inhibit mammary tumors' in mice. The group of enzymes lumbrokinase (LK) also promises to wage a 'war on cancer' (Moss, 2004).

\section{c). Anti-microbial Products from Earthworms for Production of Antibiotics}

The coelomic fluid of earthworms have been reported to have anti-pathogenic activities and are good biological compound for the production of 'antibiotics' (Pierre et, al., 1982). Several fatty acids have been isolated from earthworms. Important among them are 'lauric acid' which are known for its 'anti-microbial' properties. It is a precursor to 'monolaurin' which is a more powerful 'anti-microbial' agent that has potential to fight lipid-coated RNA and DNA viruses, several pathogenic Gram-positive bacteria, yeasts and various pathogenic protozoa (Lopez \& Alis, 2005). Peptide 'lumbricin I' isolated from L. lumbricus also exhibits antimicrobial activity against both Gram positive and Gram negative bacteria as well as fungi. 
Some biological compounds from earthworms are also finding industrial applications. Being 'biodegradable' they are environmentally friendly and sustainable. 'Stearic acid found in earthworms is a long chain saturated fatty acid and are widely used as 'lubricant' and as an 'additive' in industrial preparations. It is used in the manufacture of metallic stearates, pharmaceuticals soaps, cosmetics and food packaging. It is also used as a 'softner', 'accelerator activator' and 'dispersing agents' in rubbers. Industrial applications of lauric acid and its derivatives are as 'alkyd resins', 'wetting agents', a 'rubber accelerator' and 'softner' and in the manufacture of 'detergents' and 'insecticides' (Lopez \& Alis, 2005).

Worms are also finding new uses as a source of ‘collagen’ for pharmaceutical industries.

\subsection{Nutritive Feed Materials for Poultry, Dairy and Fishery Industries}

Earthworms are rich in high quality protein (65 \%) and is 'complete protein' with all essential amino acids. There is 70-80 \% high quality 'lysine' and 'methionine'. Glumatic acid, leucine, lysine \& arginine are higher than in fish meals. Tryptophan is 4 times higher than in blood powder and 7 times higher than in cow liver. Worms are also rich in Vitamins A \& B. There is $0.25 \mathrm{mg}$ of Vitamin $B_{1}$ and $2.3 \mathrm{mg}$ of Vitamin $B_{2}$ in each $100 \mathrm{gm}$ of earthworms. Vitamin D accounts for $0.04-0.073 \%$ of earthworms wet weight. Thus worms are wonderful probiotic feed for fish, cattle and poultry industry (Dynes, 2003). They are being used as 'additives' to produce 'pellet feeds' in the USA, Canada and Japan (Kangmin, 2005).

As earthworm protein is complete with 8-9 essential amino acids especially with the tasty 'glutamic acid' it can be used for human beings as well. Worm protein is higher than in any meat products with about $2 \%$ lower fats than in meats and ideal for human consumption.

\section{Conclusion \& Remarks}

Earthworms are proving to be great 'environmental engineers'. The vermi-composting \& vermi-agro-production technologies can together maintain the 'global human sustainability cycle' \& 'circular economy'- 'using food wastes (negative economic \& environmental value) of the society to produce food (positive socio-economic value) for the society again'. And if vermicompost can 'replace' the 'chemical fertilizers' for production of 'safe organic foods' which has now been proved worldwide, it will be a giant step towards achieving global 'social, economic \& environmental sustainability. With the growing global popularity of 'organic foods' which became a US \$ 6.5 billion business every year by 2000, there will be great demand for vermicompost in future.

In all vermiculture practices, 'worm biomass' comes as a valuable by-product which is finding new environmental and socio-economic uses. They are truly justifying the beliefs and 
fulfilling the dreams of Sir Charles Darwin who called them as 'unheralded soldiers' of mankind' and 'friends of farmers'. As environmental engineers, earthworms are both 'protective' \& 'productive' for environment and society. Future of mankind on earth beholds with the earthworms and our relationship must be maintained.

\section{References \& More Readings}

Arancon, N.Q., Edwards, C.A., Bierman, P., Welch, C. and Metzger, J.D., (2004): Influences of vermicomposts on field strawberries - 1: Effects on growth and yields; Bioresource Technology, Vol. 93: pp. 145-153.

Atiyeh, R.M., Subler, S., Edwards, C.A., Bachman, G., Metzger, J.D. Shuster, W. (2000): Effects of vermicomposts and composts on plant growth in horticultural container media and soil; Pedobiologia, Vol. 44: pp. 579-590.

Appelhof, Mary (1997): Worms eat my garbage; $2^{\text {nd }}$ (ed); Flower Press, Kalamazoo, Michigan, U.S. (http://www.wormwoman.com).

Baker, G. \& Barrett, V. (1994): Earthworm identifier; Publication of Council of Scientific \& Industrial Research Organization (CSIRO), Division of Soil \& Land Management, Australia.

Beetz, Alice (1999): Worms for composting (vermicomposting); ATTRA-National Sustainable Agriculture Information Service, Livestock Technical Note, June 1999.

Bhawalkar, U.S., (1995): Vermiculture Eco-technology; Publication of Bhawalkar Earthworm Research Institute (BERI), Pune, India.

Bogdanov, Peter (1996): Commercial vermiculture: how to build a thriving business in redworms; VermiCo Press, Oregon, 83 p.

Bogdanov, Peter (2004): The single largest producer of vermicompost in world; In P. Bogdanov (Ed.), ‘Casting Call’, Vol. 9 (3), October 2004. (http://www.vermico.com)

Bolan, N.S. and Baskaran, S. (1996): Characteristics of earthworm casts affecting herbicide sorption and movement; Biological Fertility of Soils; Vol. 22: pp. 367-372.

Bajsa, O., Nair, J., Mathew, K., \& Ho, G.E. (2003) : Vermiculture as a tool for domestic wastewater management; Water Science and Technology; IWA Publishing; Vol. 48: No 11-12; pp.125-132;

Binet, F., Fayolle, L., Pussard, M. (1998): Significance of earthworms in stimulating soil microbial activity; Biology and Fertility of Soils; Vol. 27: pp. 79-84. 
Brown, G.B., and Doube, B.M. (2004): (On earthworms assisted bioremediation) In: C.A. Edward (Ed.), Earthworm Ecology (2 ${ }^{\text {nd }}$ Ed.), CRC Press, Boca Raton, Fl , pp. 213239.

Butt, K.R. (1999): Inoculation of earthworms into reclaimed soils: the UK experience; Land Degradation and Development; Vol. 10; pp. 565-575.

Butt K.R., Lowe, C.N., Frederickson, J. \& Moffat, A.J. (2004): The development of sustainable earthworm populations at Calvert landfill site, UK; Land Degradation \& Development; Vol. 15 : pp. 27-36.

Buckerfield, J.C., Flavel, T.C., Lee, K.E. and Webster, K.A. (1999): Vermicompost in solid and liquid forms as a plant - growth promoter; Pedobiologia, Vol. 43: pp. 753 - 759.

Buckerfield, J.C., and Webster, K.A. (1998): Worm-worked waste boost grape yield: prospects for vermicompost use in vineyards; The Australian and New Zealand Wine Industry Journal, Vol. 13: pp.73-76.

Chaoui, H.I., Zibilske, L.M. \& Ohno, T. (2003): Effects of earthworms casts and compost on soil microbial activity and plant nutrient availability; Soil Biology and Biochemistry, Vol. 35, No. 2; pp. 295-302.

Contreras-Ramos, Silvia M., Alvarez-Bernal D. \& Dendooven L. (2006): Eisenia fetida increased removal of polycyclic aromatic hydrocarbons (PAHs) from soil; Environmental Pollution; Vol. 141: pp. 396-401; Elsevier Pub.

Cordero, C.H. (2005): Earthworms can help dissolve blood clots for stroke patients; http://www.thenewstoday.info/20051125/earthworms.can.help.dissolve.blood.clots.for. stroke.patients.html )

Cooper, Edwin (2009): New Enzymes Isolated from Earthworms is Potent Fibrinolytic; ACAM Integrative Medicine Blog; Oxford University Press Journal (UK). (http://acam.typepad.com/blog/2009/04/index.html)

Davis, B. (1971): Laboratory studies on the uptake of dieldrin and DDT by earthworms; Soil Biology and Biochemistry; Vol.3, pp. 221-223.

Dash, M.C. (1978): Role of earthworms in the decomposer system; In: J.S. Singh and B. Gopal (eds.) Glimpses of Ecology; India International Scientific Publication, New Delhi, pp.399-406.

Datar, M.T., Rao, M.N. and Reddy, S. (1997): Vermicomposting : a technological option for solid waste management; Solid Waste Technology and Management, Vol. 24 (2); pp. 89-93. 
Dynes, R.A. (2003): EARTHWORMS; Technology Info to Enable the Development of Earthworm Production; Rural Industries Research and Development Corporation (RIRDC), Govt. of Australia, Canberra, ACT.

Edwards, C.A. (1988): Breakdown of animal, vegetable and industrial organic wastes by earthworms; In C.A. Edward, E.F. Neuhauser (ed). 'Earthworms in Waste and Environmental Management'; pp. 21-32; SPB Academic Publishing, The Hague, The Netherlands; ISBN 90-5103-017-7

Edwards, C.A. and Burrows, I. (1988): The potential of earthworms composts as plant growth media; In C.A. Edward and E.F. Neuhauser (Eds.) 'Earthworms inWaste and Environmental Management'; SPB Academic Publishing, The Hague, The Netherlands; ISBN 90-5103-017-7; pp. 21-32.

Edwards, C.A. (1998): The use of earthworms in the breakdown and management of organic wastes; In C.A. Edwards (Ed.), Earthworm Ecology; CRC Press, Boca Raton, FL, USA, pp. $327-354$.

Edward, C.A. (2000): Potential of vermicomposting for processing and upgrading organic waste; Ohio State University, Ohio, U.S.

Edwards, C.A. and Fletcher, K.E. (1988): Interaction between earthworms and microorganisms in organic matter breakdown; Agriculture Ecosystems and Environment; Vol. 24, pp. 235-247.

Edwards, C.A. and Arancon, N. (2004): Vermicompost suppress plant pests and disease attacks; In REDNOVA NEWS: http://www.rednova.com/display/ ?id =55938

Eijsackers, H., Van Gestel, C.A.M., De Jonge, S., Muijis, B., Slijkerman, D. (2001): PAH polluted dredged peat sediments and earthworms: a mutual inference; Ecotoxicology; Vol. 10: pp. 35-50.

Fraser-Quick, G. (2002): Vermiculture - a sustainable total waste management solution; What's New in Waste Management? Vol. 4, No.6; pp. 13-16.

Frederickson, J. (2000): The worm’s turn; Waste Management Magazine; August, UK.

Gevao, B., C. Mordaunt, K.T. Semple, T.G. Piearce and K.C. Jones (2001): Bioavailability of non-extractable (bound) pesticide residues to earthworms; Environmental Science \& Technology; Vol. 35, pp. 501-507

GEORG (2004): Feasibility of developing the organic and transitional farm market for processing municipal and farm organic wastes using large - scale vermicomposting; Pub. Of Good Earth Organic Resources Group, Halifax, Nova Scotia, Canada. (Available on http://www.alternativeorganic.com) 
Graff, O. (1981): Preliminary experiment of vermicomposting of different waste materials using Eudrilus eugeniae Kingberg; In: M. Appelhof (ed.) Proc. of the workshop on 'Role of Earthworms in the Stabilization of Organic Residues'; Malanazoo Pub. Michigan, USA.; pp.179-191.

Haimi, J., Salminen, J., Huhta,V., Knuutinen, J., and Palm, H. (1992): Bioaccumulation of organochlorine compounds in earthworms; Soil Biology \& Biochemistry; Vol. 24 (12), pp. 1699-1703.

Hartenstein, R., Neuhauser, E.F. and Collier, J. (1980): Accumulation of heavy metals in the earthworm E. foetida; Environmental Quality; Vol. 9; pp. 23-26.

Hartenstein, R. and Hartenstein, F. (1981): Physico-Chemical Changes Affected in Activated Sludge by the Earthworms Elsenia fetida; J. of Environmental Quality, Vol. 10 (3); pp. 377-382.

Hwang, C.M., Kim, Di. \& Huh, S.H.(2002): In - vivo evaluation of lumbrokinase extracted from earthworms Lumbricus rubellus in a prosthetic vascular graft; Cardiovascular Surgery; Vol. 43: pp. 891-894.

Hughes R. J., Nair, J. and Mathew K. (2005): The implications of wastewater vermicomposting technologies: on-site treatment systems for sustainable sanitation; WAMDEC Conference, Zimbabwe, July 27-30.

Ireland, M.P. (1983): Heavy metals uptake in earthworms; Earthworm Ecology; Chapman \& Hall, London.

Jin, L., Jin, H., Zhang, G. \& Xu G. (2000): Changes in coagulation and tissue plasminogen activator after the treatment of cerebral infarction with lumbrokinsae (from earthworms); Clinical Hemorheol Microcirc.; Vol. 23: pp. 213-218.

Kale, R.D. (1998): Earthworms : nature’s gift for utilization of organic wastes; In C.A. Edward (ed). 'Earthworm Ecology'; St. Lucie Press, NY, ISBN 1-884015-74-376.

Kale, R.D., and Bano, K. (1986): Field trials with vermicompost: an organic fertilizer; In Proc. Of National Seminar on 'Organic Waste Utilization by Vermicomposting'; GKVK Agricultural University, Bangalore, India.

Kangmin, Li (1998): Earthworm case; $4^{\text {th }}$ ZERI World Congress; Windhoel, Namibia.(Also in Vermiculture Industry in Circular Economy; Worm Digest (2005) ( http://www.wormdigest.org/content/view/135/2/ )

Komarowski, S. (2001) Vermiculture for sewage and water treatment sludge. WATER; Publication of Australian Water and Wastewater Association; July 2001; pp 39-43. 
Li, S.L. (1995): Research on di long's (earthworms) effect in lowering blood pressure; J. of Information; Vol. 12 (3): 22-24.

Loehr, R.C., Martin, J.H., Neuhauser, E.F. and Malecki, M.R. (1984): Waste management using earthworms - engineering and scientific relationships; Project Report ISP 8016764; National Science Foundation, Washington D.C.

Lopez, A. and Alis, R. (2005): Indigenous use of native earthworms and its fatty acids profile; Paper Presented at the Int. Symposium on 'Vermitechnologies for Developing Countries’; Laguna, Philippines (mjanglopez@yahoo.ca) (Also in Utilization of Earthworms for Health Remedies ( http://www.wormsphilippines.com/docs/IKs\%20on\%20Earthworms.htm )

Lotzof, M. (2000): Vermiculture: an Australian technology success story; Waste Management Magazine; February 2000, Australia.

Lowe, C.N., Butt, K.R. (2003): Inoculation of earthworms into reclaimed soils: experiences from Britain; Proc. Of Ninth International Waste Management and Landfill Symposium.

Martin-Gil, J., Navas-Gracia, L.M., Gomez-Sobrino, E., Correa-Guimaraes, A., HernandezNavarro, S., and Sanchez-Bascones, M. (2007): Composting and vermicomposting experiences in the treatments and bioconversion of asphaltens from the Prestige oil spill; Bioresource Technology; Vol. 99: pp. 1821-1829.

Markman, S.I., Guschina. A., Barnsleya, S., Katherine, L. David, B. and Muller, C.T. (2007) : Endocrine disrupting chemicals accumulate in earthworms exposed to sewage effluents; CHEMOSPHERE ; Vol. 70 (1): pp. 119 - 125.

Mihara, H., Sumi, M., Mizumoto, H., Yoneta, T., Ikeda, R., \& Maruyama, M. (1990): Oral administration of earthworm powder as possible thrombolytic therapy; Recent Advances in Thrombosis and Fibrinolysis; Academic Press, NY: pp. 287-298.

Mihara, H., Maruyama, M., and Sumi, M. (1992): Novel thrombolytic therapy discovered in oriental medicine using the earthworms; SE Asian Journal of Tropical Medicine \& Health; pp. 131-140.

Munroe, Glenn (2007): Manual of on-farm vermicomposting and vermiculture; Pub. of Organic Agriculture Centre of Canada; 39 p.

Morgan, M. \& Burrows, I., (1982): Earthworms / microorganisms interactions; Rothamsted Exp. Stn. Rep. 
Ma, W.C., Imerzeel and Bodt, J. (1995): Earthworm and food interactions on bioaccumulation and disappearance of PAHs : studies on phenanthrene and flouranthene; Ecotoxicology and Environmental Safety; Vol. 32: 226-232.

Moss, Ralph (2004): Of enzymes, worms \& cancer : the war on cancer (lumbrokinsae enzyme from earthworms); Worm Digest; ( http://www.wormdigest.org/content view/161/2/)

NCSU (1997): Large scale vermi-composting operations - data from Vermi-cycle Organics, Inc.; North Carolina State University, U.S.

Neilson, R.L. (1965). Presence of plant growth substances in earthworms, demonstrated by the paper chromatography and went pea test; Nature, (Lond.) 208 : 1113-1114.

NIIR (2009): The complete technology book on vermiculture and vermicompost'; Pub. Of National Institute of Industrial Research; New Delhi, India; ISBN 8186623817;

Pajon, Silvio (Undated): 'The worms turn - Argentina'; Intermediate Technology Development Group; Case Study Series 4; (Quoted in Munroe, 2007).

Palanisamy, S. (1996): Earthworm and plant interactions; Paper presented in ICAR Training Program; Tamil Nadu Agricultural University, Coimbatore.

Pierre, V, Phillip, R. Margnerite, L. and Pierrette, C. (1982): Anti-bacterial activity of the haemolytic system from the earthworms Eisinia foetida andrei; Invertebrate Pathology, 40, pp. 21-27.

Qingsui, C. (2003): A new medicine for heart diseases containing enzyme activator extracted from earthworms; (In Lopez \& Alis 'The Utilization of Earthworms for Health Remedies). mjanglopez@yahoo.com

Ramteke, P.W. and Hans, R.K. (1992): Isolation of hexachlorocyclohexane (HCH) degrading microorganisms from earthworm gut; Environmental Science \& Health ; Vol. 27 (8): pp. 2113-2122.

Satchell, J. E. (1983) : Earthworm ecology- from Darwin to vermiculture; Chapman and Hall Ltd., London; pp.1-5.

Sadhale, Nailini (1996) : (Recommendation to incorporate earthworms in soil of pomogranate to obtain high quality fruits); In Surpala's Vrikshayurveda, Verse 131. (The Science of Plant Life by Surpala, $10^{\text {th }}$ Century A.D.); Asian Agri-History Bulletin; No. 1; India.

Safawat, H., Hanna, S., Weaver, R.W. (2002): Earthworms survival in oil contaminated soil; Plant and Soil; Vol. 240: pp. 127-132. 
Saxena, M., Chauhan, A., and Asokan, P. (1998): Flyash vemicompost from non-friendly organic wastes; Pollution Research, Vol.17, No. 1; pp. 5-11.

Schaefer, M. (2005): Earthworms in crude oil contaminated soils: toxicity tests and effects on crude oil degradation; Contaminated Soil Sediment \& Water; 35 : 7 - 8.

Sherman, Rhonda (2000): Commercial systems latest development in mid-to-large scale vermicomposting; Biocycle; November 2000, pp. 51.

Singleton, D.R., Hendrix, B.F., Coleman, D.C., Whitemann, W.B. (2003): Identification of uncultured bacteria tightly associated with the intestine of the earthworms Lumricus rubellus; Soil Biology and Biochemistry; Vol. 35: pp. 1547-1555.

Sinha, R.K., Herat, Agarwal, S. Asadi, R., \& Carretero, E. (2002): Vermiculture technology for environmental management: study of action of earthworms elsinia foetida, eudrilus euginae and perionyx excavatus on biodegradation of some community wastes in India and Australia; The Environmentalist, U.K., Vol. 22, No.2. pp. 261 - 268.

Sinha, R.K., Herat, S., Bapat, P.D., Desai, C., Panchi, A. \& Patil, S. (2005): Domestic waste the problem that piles up for the society: vermiculture the solution; Proceedings of International Conference on 'Waste-The Social Context; May 11-14, 2005, Edmonton, Alberta, Canada; pp. 55-62.

Sinha, R.K., Bharambe, G. \& Bapat, P.D. (2007): Removal of high bod \& cod loadings of primary liquid waste products from dairy industry by vermi-filtration technology using earthworms; Indian Journal of Environmental Protection (IJEP), Vol. 27, Number 6, pp. 486-501; ISSN 0253-7141.

Sinha, R.K, Bharambe, G. \& Chowdhary, U. (2008 a): Sewage treatment by vermi-filtration with synchronous treatment of sludge by earthworms: a low-cost sustainable technology over conventional systems with potential for decentralization; The Environmentalist; UK ; Vol. 28: pp. 409 - 420; Published Online 8 April 2008, Springer, USA.

Sinha, R.K, Bharambe, G. \& Ryan, D. (2008 b):Converting wasteland into wonderland by earthworms: a low-cost nature's technology for soil remediation : a case study of vermiremediation of PAH contaminated soil; The Environmentalist; UK; Vol. 28: pp. 466 - 475; Published Online 14 May 2008, Springer, USA.

Sinha, Rajiv K. (2009): Earthworms: the miracle of nature (Charles Darwin’s 'unheralded soldiers of mankind and farmer's friends'); Guest Editorial (The Environmentalist); UK; Published Online: 05 August, 2009. 
Sinha, Rajiv K. and Andrew Chan (2009): Study of emission of greenhouse gases by Brisbane households practicing different methods of composting of food \& garden wastes: aerobic, anaerobic and vermicomposting”; NRMA - Griffith University Project Report (2009) (Rajiv.Sinha@griffith.edu.au);

Sinha, R.K., Herat, S., Bharambe,G., Patil, S., Bapat, P.D. Chauhan, K. \& Valani, D. (2009 a): Vermiculture biotechnology: the emerging cost-effective and sustainable technology of the $21^{\text {st }}$ century for multiple uses from waste $\&$ land management to safe \& sustained food production; Environmental Research Journal; Vol. 3 (Issue 1); pp. 41-110; NOVA Science Publishers, NY, USA.

Sinha, R.K., Herat, S., Valani, D. \& Chauhan, K. (2009 b): "Vermiculture and sustainable agriculture'; American-Eurasian J. of Agricultural and Environmental Sciences; ISSN 1818: 5 (S); pp. 01- 55; IDOSI Publication (www.idosi.org.)(Special Issue);

Sinha, R.K., Herat, S. Bharambe, G. \& Brahambhatt, A. (2009 c): Vermistabilization of sewage sludge (biosolids) by earthworms: converting a potential biohazard destined for landfill disposal into a pathogen free, nutritive \& safe bio-fertilizer for farms; J. of Waste Management \& Research; UK. (Published On-line 26 August, 2009) (http://sagepub.com).

Soto, M.A. and Toha, J. (1998): Ecological wastewater treatment; Advanced wastewater treatment, recycling and reuse; AWT 98; Milano, September 14-16, 2008. (Email: masoto@cec.uchile.cl)

Suhane, R.K., 2007. Vermicompost; Pub. Of Rajendra Agriculture University, Pusa, Bihar; pp: 88 (www.kvksmp.org) (Email: info@kvksmp.org).

Tomati, V.; Grappelli, A. and Galli, E. (1987): The presence of growth regulators in earthworm - worked wastes; In Proceeding of International Symposium on 'Earthworms'; Italy; 31 March- 5 April, 1985; pp. 423-436.

Visvanathan, C., Trankler, J., Jospeh, K., \& Nagendran, R.. (Eds.):(2005): Vermicomposting as an Eco-tool in Sustainable Solid Waste Management; Asian Institute of Technology, Anna University, India.

Wang, Z.W. (2000): Research advances in earthworms bioengineering technology; Medica; Vol. 31(5): pp. 386-389.

Wang, F., Wang, C., Li, M., Gui, L., Zhang, J., and W. Chang (2003): Purification, characterization and crystallization of a group of earthworms fibrinolytic enzymes from Eisenia fetida; Biotechnology; Vol. 25 (13): pp. 1105-1109. 
Wengling, C. and S. Jhenjun (2000): Pharmaceutical value and uses of earthworms; Vermillenium Abstracts; Flowerfield Enterprizes, Kalamazoo, MI (USA).

Webster, K.A. (2005): Vermicompost increases yield of cherries for three years after a single application; EcoResearch, South Australia; (www.ecoresearch.com.au)

Xing M., Yang, J. and Lu, Z. (2005): Microorganism-earthworm integrated biological treatment process - a sewage treatment option for rural settlements; ICID $21^{\text {st }}$ European Regional Conference, 15-19 May 2005; Frankfurt.

Useful websites on vermiculture studies http://www.alternativeorganic.com (Good Earth People, Canada). http://www.rirdc.gov.au (Australian Govt. Pub. On EARTHWORMS). http://www.vermitech.com (Australian Company in Vermiculture Business). http://www.vermitechnology.com (U.S. Company in Vermiculture Business). http://www.wormwoman.com (Mary Appelhof: Classic Book 'Worms Eat My Garbage-Sold over 3500 copies). http://www.wormdigest.org ('Worm Digest'-A Quarterly Magazine). http://www.wormresearchcentre.co.uk (Earthworm Research Center in UK). http://www.wormdigest.org/content/view/355/2/ (Modern Medicines from

Earthworms)

\section{Tables}

Table - 1:

Degradation of Mixed Food \& Garden Wastes by Vermicomposting Vis -à- vis Conventional Composting Systems in Methodical \& Casual Ways

\begin{tabular}{|c|c|c|c|c|}
\hline \multirow[t]{2}{*}{ Waste Materials } & \multicolumn{2}{|c|}{$\begin{array}{l}\text { Vermicomposting With } \\
\text { Earthworms (1000) } \\
\text { (Degradation in \%) }\end{array}$} & \multicolumn{2}{|c|}{$\begin{array}{c}\text { Conventional Composting } \\
\text { Without Worms } \\
\text { (Degradation in \%) } \\
\end{array}$} \\
\hline & Methodical & Casual & Methodical & Casual \\
\hline
\end{tabular}

1. Mixed Food Waste

(4 kg)

After 24 hours

After 15 Days

After 30 Days

$100 \%$

0

100

60

0

After 45 Days

100

60

After 60 Days

100

70

After 75 Days

100

70

80

100

$90 \%$

0

0

After 90 Days

$90 \%$

0

0

5

25

0

2. Garden Waste

(1 kg)

After 15 Days 


\begin{tabular}{lcccc} 
After 30 Days & 35 & 15 & 0 & 0 \\
After 45 Days & 40 & 18 & 0 & 0 \\
After 60 Days & $\mathbf{1 0 0} \%$ & 70 & 15 & 10 \\
After 75 Days & 100 & 70 & 20 & 10 \\
After 90 Days & 100 & $\mathbf{8 0} \%$ & $\mathbf{3 5 \%}$ & $\mathbf{1 2} \%$ \\
\hline
\end{tabular}

Table- 2:

Removal of BOD, COD and TSS of Municipal Wastewater (Sewage) Treated by Earthworms (Vermifiltered) \& Without Earthworms (In mg/L) (HRT: 1- 2 hrs)

\begin{tabular}{|c|c|c|c|c|c|}
\hline \multirow[t]{2}{*}{$\begin{array}{l}\text { Parameters } \\
\text { Studied }\end{array}$} & \multirow{2}{*}{$\begin{array}{c}\text { Untreated } \\
\text { Raw } \\
\text { Sewage } \\
\text { (mg/L) }\end{array}$} & \multicolumn{2}{|c|}{$\begin{array}{c}\text { Treated Sewage } \\
\text { Reduction in Values }(\mathrm{mg} / \mathrm{L})\end{array}$} & \multirow{2}{*}{$\begin{array}{l}\text { \% Reduction by } \\
\text { Earthworms } \\
\text { (Vermifiltered) }\end{array}$} & \multirow{2}{*}{$\begin{array}{l}\text { \% Reduction } \\
\text { Without } \\
\text { Earthworms } \\
\text { (Control) }\end{array}$} \\
\hline & & $\begin{array}{c}\text { With } \\
\text { Worms } \\
\text { (Vermifiltered) }\end{array}$ & $\begin{array}{l}\text { Without } \\
\text { Worms } \\
\text { (Control) }\end{array}$ & & \\
\hline $\mathrm{BOD}_{5}$ & 309 & 1.97 & 86.3 & $99.4 \%$ & $72.1 \%$ \\
\hline COD & 293 & 132 & 245 & $54.9 \%$ & $16.4 \%$ \\
\hline TSS & 438 & 22 & 184 & $94.97 \%$ & $57.99 \%$ \\
\hline
\end{tabular}

Table - 3:

Percent Removal of Some PAH Compounds from Contaminated Soil

by Earthworms in 12 Weeks Periods

\begin{tabular}{|c|c|c|c|}
\hline $\begin{array}{l}\text { Extracted } \\
\text { Compounds }\end{array}$ & $\begin{array}{c}\text { Treatent-1 } \\
\text { Soil + Worms + } \\
\text { Cow Dung }\end{array}$ & $\begin{array}{c}\text { Treatent-2 } \\
\text { Soil + Worms + } \\
\text { Food Wastes }\end{array}$ & $\begin{array}{c}\text { Treatent-3 } \\
\text { Soil + Compost } \\
\text { (NO WORMS) }\end{array}$ \\
\hline 1.Benzo (a) anthracene & $76 \% \quad(58 \%)$ & $71 \% \quad(56 \%)$ & $37 \% \quad(6 \%)$ \\
\hline 2.Chrysene & $67 \% \quad(49 \%)$ & $83 \% \quad(68 \%)$ & $41 \% \quad(12 \%)$ \\
\hline 3.Benzo(b) flouranthene & $90 \% \quad(72 \%)$ & $97 \% \quad(82 \%)$ & $65 \% \quad(47 \%)$ \\
\hline 4.Benzo (k) flouranthene & $90 \% \quad(72 \%)$ & $80 \% \quad(65 \%)$ & $40 \% \quad(10 \%)$ \\
\hline 5.Benzo (a) pyrene & $89 \% \quad(71 \%)$ & $78 \% \quad(63 \%)$ & $49 \% \quad(24 \%)$ \\
\hline $\begin{array}{l}\text { 6.Dibenzo (a,h) pyrene \& } \\
\text { Benzo (g,h,i) pyrene }\end{array}$ & $83 \% \quad(65 \%)$ & $54 \% \quad(39 \%)$ & $(30 \%)$ \\
\hline Av. $=$ & $79 \% \quad(61 \%)$ & $80 \% \quad(65 \%)$ & $47.5 \%(21 \%)$ \\
\hline
\end{tabular}

(Soil = 10 kg; Earthworms = 500; Cow Dung \& Food Wastes = 5 kg).

(Values within bracket are those after taking the dilution factor into consideration due to mixing of feed materials into soil).

Table - 4:

Growth of Potted Egg Plants Promoted by Vermicompost, Worms

With Vermicompost \& Chemical Fertilizer

\begin{tabular}{lccccc}
\hline Treatments & $\begin{array}{c}\text { Av. Growth } \\
\text { (In Inches) }\end{array}$ & $\begin{array}{c}\text { Av. No. of } \\
\text { Fruits/ Plant }\end{array}$ & $\begin{array}{c}\text { Av. Wt. of } \\
\text { Fruits/ Plant }\end{array}$ & $\begin{array}{c}\text { Total No. Max. Wt. of } \\
\text { of Fuits }\end{array}$ & $\begin{array}{c}\text { One Fruit } \\
\text { Ond }\end{array}$ \\
\hline 1. EW + VC & 28 & 20 & $675 \mathrm{gm}$ & 100 & $900 \mathrm{gm}$ \\
2. VC & 23 & 15 & $525 \mathrm{gm}$ & 75 & $700 \mathrm{gm}$ \\
3. CF & 18 & 14 & $500 \mathrm{gm}$ & 70 & $625 \mathrm{gm}$ \\
4. CONTROL & 16 & 10 & $425 \mathrm{gm}$ & 50 & $550 \mathrm{gm}$ \\
\hline
\end{tabular}

Keys: EW=Earthworms (50); VC=Vermicompost (250 gm); CF=Chemical Fertilizer (Full Dose). 
Table - 5:

Growth of Potted Okra Plants Promoted by Vermicompost, Worms With Vermicompost \& Chemical Fertilizer

\begin{tabular}{lccccc}
\hline Treatment & $\begin{array}{c}\text { Av. Growth } \\
\text { (In Inches) }\end{array}$ & $\begin{array}{c}\text { Av. No. of } \\
\text { Fruits/ } \\
\text { Plant }\end{array}$ & $\begin{array}{c}\text { Av. Wt. of } \\
\text { Fruits/ Plant }\end{array}$ & $\begin{array}{c}\text { Total No. } \\
\text { of Fruits }\end{array}$ & $\begin{array}{c}\text { Max. Wt. of } \\
\text { One Fruit }\end{array}$ \\
\hline 1. EW + VC & 39.4 & 45 & $48 \mathrm{gm}$ & 225 & $70 \mathrm{gm}$ \\
2. VC & 29.6 & 36 & $42 \mathrm{gm}$ & 180 & $62 \mathrm{gm}$ \\
3. CF & 29.1 & 24 & $40 \mathrm{gm}$ & 125 & $48 \mathrm{gm}$ \\
4. CONTROL & 25.6 & 22 & $32 \mathrm{gm}$ & 110 & $43 \mathrm{gm}$ \\
\hline
\end{tabular}

Keys: EW=Earthworms (50); VC=Vermicompost (250 gm); CF=Chemical Fertilizer (Full Dose).

Table - 6 :

Growth of Potted Corn Plants Promoted by Earthworms, Vermicompost With Worms \& Chemical Fertilizers (EW 25 Nos.; VC 200 gm; CF 8 gm in 4.5 L Water; Pot Soil 7 kg; Av. Growth in cm)

\begin{tabular}{lccccc}
\hline Treatments & Week 4 & Week 6 & Week 12 & Week 15 & Week 19 \\
\hline 1). Control & 31 & 44 & 46 & 48 & 53 \\
\hline 2). EW Only & 40 & 47 & 53 & 53 & 56 \\
3). CF & $\mathbf{4 3}$ & $\mathbf{6 1}$ & $\mathbf{8 7}$ & $\mathbf{8 8}$ & $\mathbf{9 2}$ \\
4). VC + EW & $\mathbf{4 3}$ & $\mathbf{5 8}$ & $\mathbf{9 0}$ & $\mathbf{9 5}$ & $\mathbf{1 0 5}$ \\
\hline
\end{tabular}

Keys: $\mathrm{EW}=$ Earthworms; $\mathrm{VC}=$ Vermicompost; $\mathrm{CF}=$ Chemical fertilizers

Table - 7 :

Growth of Potted Wheat Crops Promoted by Vermicompost,

Conventional Compost and Chemical Fertilizers

(VC 500 gm; EW 25 Nos.; CC 500 gm; CF 5 gm x 3 times; Av. Growth in cm)

\begin{tabular}{lllll}
\hline Treatments & Week 1 & Week 5 & Week 10 & Week 12 \\
\hline 1). Control & 17 & 22 & 26 & 26 \\
2). CC & 17 & 31 & 32 & 32 \\
3). CF & $\mathbf{1 6}$ & $\mathbf{3 6}$ & $\mathbf{3 9}$ & $\mathbf{4 3}$ \\
4). VC + EW & $\mathbf{1 9}$ & $\mathbf{3 9}$ & $\mathbf{4 3}$ & $\mathbf{4 7}$
\end{tabular}

Keys: CC = Conventional Compost; $\mathrm{CF}=$ Chemical Fertilizer; VC = Vermicompost; EW = Earthworms

Table - 8:

Growth \& Yield of Farmed Wheat Crops Promoted by Vermicompost, Cattle Dung Compost and Chemical Fertilizers

\begin{tabular}{llc}
\hline Treatments & Input/Hectare & $\begin{array}{c}\text { Yield/ } \\
\text { Hectare }\end{array}$ \\
\hline 1). CONTROL & (No Input) & $15.2 \mathrm{Q} / \mathrm{ha}$ \\
2). Vemicompost (VC) & 25 Quintal VC / ha & $\mathbf{4 0 . 1} \mathbf{Q} / \mathbf{h a}$ \\
3). Cattle Dung Compost & 100 Quintal CDC / ha & $33.2 \mathrm{Q} / \mathrm{ha}$ \\
4). Chemical Fertilizers & NPK (120:60:40) $\mathbf{~ k g ~ / ~ h a ~}$ & $\mathbf{3 4 . 2} \mathbf{Q} / \mathbf{h a}$ \\
5). CF + VC & NPK (120:60:40) kg/ha + 25 Q VC / ha & $43.8 \mathrm{Q} / \mathrm{ha}$ \\
6). CF + CDC & NPK(120:60:40) kg/ha +100Q CDC/ ha & $41.3 \mathrm{Q} / \mathrm{ha}$ \\
\hline
\end{tabular}

Keys: N = Urea; P = Single Super Phosphate; K = Murete of Potash (In Kg / ha) 